\title{
Research on the Public Land Management in the United States and Its Reference for China
}

\author{
Qiqi Zhang1, Mu Zhang2* \\ ${ }^{1}$ Public Management School, Jinan University, Guangzhou, China \\ ${ }^{2}$ Shenzhen Tourism School, Jinan University, Shenzhen, China \\ Email: zhangqq@stu2016.jnu.edu.cn, *zhangmu@163.com
}

How to cite this paper: Zhang, Q.Q. and Zhang, M. (2018) Research on the Public Land Management in the United States and Its Reference for China. American Journal of Industrial and Business Management, 8, 985-991.

https://doi.org/10.4236/ajibm.2018.84067

Received: April 3, 2018

Accepted: April 25, 2018

Published: April 28, 2018

Copyright $\odot 2018$ by authors and Scientific Research Publishing Inc. This work is licensed under the Creative Commons Attribution International License (CC BY 4.0).

http://creativecommons.org/licenses/by/4.0/

\begin{abstract}
The public land management in the United States has experienced these processes: extensive management to encourage land privatization-beginning to pay attention to the protection of public lands-protective development of public land. This article aims to explore the similarities and differences between China and the United States in the management of public land. From the perspective of organization, law and public interest, it provides reference for China's land management theory and practice. This paper found that at present, the features of public land management in USA are sound management institutions, complete laws and regulations, strict land use management system, strict implementation of paid land use, and implementation of public regulation of non-ownership. The legal system of land in the United States, the strict programming of land planning and the land property and market system are worthy of learning.
\end{abstract}

\section{Keywords}

Public Land in US, Privatization, Land System

\section{Introduction}

The United States is a highly developed country with vast territory, abundant resources, but few people. The natural and geographical conditions of the 50 states vary in different ways. Most lands are private while there are federal and state ownership. In the west a large number of public lands are distributed such as forest, park, and so on. Although America is quite different from China in terms of natural, social environment and system, its management system in public land still has a realistic reference.

Based on the review and analysis of the history of public land management in 
the United States, the characteristics of present stage are refined. Considering the reality and limitations of China's land management, suggestions are provided for the promotion of scientific, rational and efficient land use. However, because of the great political, social and economic differences between China and the United States, the experience of land management cannot be copied. It is worth further exploring how to seek the objects of similar background according to specific cases.

The article is organized as follows: introduction of history of American land management; analysis of the characteristics of the current system of public land management in US; suggestions of the reference to China based on American public land management; summary.

\section{History of American Land Management}

So far, the management of public land in America has been nearly 200 years. In different stages, different management policies were implemented for land use [1]. According to management purpose, management guidance tendency and specific management measures, it can be roughly divided into three stages as follows.

\subsection{Mid Nineteenth Century to Nineteen Thirty}

At this stage, the main purpose of land and resources management, especially public land management, is to transfer public lands belonging to the state to private property, so as to encourage settlement and development. This extensive way of land management was determined by the economic and social development requirements at that time. When the United States became an independent country in 1787, the government acquired a lot of land along the coast of the Atlantic [2]. The land was mainly distributed in the west. As a result, the American government has become a powerful owner of land, which extends from the North American continent to the Pacific coastline. But it didn't result in economic and social development; the wealth of nations didn't increase in magnitude. Because of small sedentary population in the western rural areas, almost no land was developed independently, it is necessary for the government to input a lot for the maintenance of the land. In this process, the government gradually realized the importance of private ownership, and began to consider selling a large number of public lands to individuals and allowing land to be freely traded between individuals [3].

Since the mid nineteenth Century to 1930s, the US government implemented many policies to encourage the development of privatization of public land, and the corresponding land registration institutions were established to protect the rights of land owners [4]. Meanwhile, the federal, state, and local governments retained part of the land, mainly for the construction of public projects, such as public transport, public services (schools, government buildings, police stations, fire facilities, etc.), public infrastructure and so on. And some poor, remote pub- 
lic land, the government continued to hold, and gradually transformed them into national parks, nature reserves or military bases, in order to maximize the economic benefits.

\subsubsection{0s to $1960 \mathrm{~s}$}

The last stage of public land management greatly promoted the development and utilization of public land in US, but excessive development also led to many economic, social and ecological problems. So, the government began to take multi-purpose use as the main goal of public land management, so as to prevent the adverse effects. This stage of public land management was still a continuation of extensive management at the last stage, but the government issued a series of laws and regulations to limit and protect it by purchase, confiscation and exchange.

\subsection{0s to Now}

Based on the implementation of land zoning management in 1930s, many states began to implement strict legal planning and scientific management of public land through relevant laws and regulations. In 1960s, the United States entered the stage of scientific and legal management when it focused more on the protection of the ecological environment. In the national environmental policy promulgated in 1969, the public land and public resources were also protected while developed [5].

\section{The Characteristics of the Current System of Public Land Management in US}

\subsection{Complete Management System}

In the United States, public land generally refers to the land owned by the federal government, which accounts for roughly $1 / 3$ of the total area. It was mainly used for water resources, timber, mineral resources, wildlife management, landscapes, environmental education and so on. In order to strengthen the function of public land management, as early as 1903, the federal government set up the Federal Land Reclamation Bureau under the Ministry of agriculture to ensure the most adequate, effective and lasting use of public land and all kinds of resources attached to it. In 1997, the U.S. Congress passed the federal land policy and management act, which further clarified and defined the status and responsibilities of public land management. At present a centralized, unified, comprehensive, vertical four land management network has been established. The right and responsibility between different level governments are clear in laws and each performs its own functions [6].

\subsection{Comprehensive Legal and Regulatory System}

The Federal Land Reclamation Act, signed by President Roosevelt in 1902, was a symbol of the great transformation of the US agricultural policy and land re- 
sources protection, which started a legal stage for land protection. At the same time, the federal government and state government also issued a series of laws and regulations according to the constitution of the United States, such as the first land law in 1785, the U.S. Congress passed the "federal land policy and Management Act" in 1997 [7]. Up to now a comprehensive land resource management system has been formed which provides a complete and perfect legal basis for public land management.

\subsection{Strict Land Use Management System}

The increase in population and economic development accelerated the process of industrialization and urbanization in the United States. A large number of high quality farmland was appropriated. According to incomplete statistics, the prime farmland in the United States reduced by an average of 2 million acres per year, which triggered a series of economic, social and environmental ecological problems. Therefore, many states took a series of measures to control the scale of urban development, protected high-quality farmland and public land, turned the contents of land use management to urban scale control and agricultural land protection. It's not allowed to requisition public land or farmers' land for business investment casually. Instead of expropriation, the governments try to encourage the protection of land [8].

\subsection{Strict Management of Paid Use of Land}

In America, land can be bought, sold and rented. Sometimes the federal government needs to occupy state owned or private land in order to build railways, highways and other facilities for national and social public welfare. At that time, land must also be obtained by exchange or purchase. The government can purchase or even expropriate land for public use, but it must give reasonable compensation to the seller of the land, which at least ensures that the land owner's situation will not change before and after the land expropriation. There are couples of reasons as follows: The first is to protect the security of private property, let the land owner be able to develop land without worries. The second is to reflect the fairness of the public land management system, the cost of the whole society cannot be transferred to the land expropriated individual;

The third is to reduce the resistance from the public. The forth is to limit the government's abuse of power through higher cost of land expropriation.

\subsection{Public Control of Non-Ownership}

In the process of using private land, the US government implemented non proprietary public control. The government in US rarely intervenes in private economic activities, but the government can exercise non-ownership public control when the individual exerted negative external effects. On the authority of control, the central government and the local governments have a clear division of labor according to the scope of their external effects, but only in a very small 
scope, only for few land exploitation behaviors that will damage others [9]. The most important goal is to protect people's legitimate rights.

\section{The Reference to China Based on American Public Land Management}

\subsection{Speed up the Process of Legalization of Land Resources Management}

The United States, from the federal government to the state, county and city, has a complete set of laws and regulations for the management of land resources, the protection of land and resources, the development and utilization of land and the management of real estate. In china, the legal system is not complete. Although the implementation of the new land management law and other regulations has achieved significant results, it is not clear enough in terms of description and the operation.

\subsection{Improve the Process of Land Use Planning}

Land-use plan is the basis and guarantee for land use control and management. In the United States, all kinds of planning should be carried out in accordance with the principles of democracy and public. At present, the problem in China is that the authority of land planning is poor, the process of compilation is basically closed, the decision of the target and the decomposition of the index are lack of science, and the arbitrariness of the planning changes is strong. The core reason for this problem is that the government is not only the planning department but also the management department of the land [10]. At the same time, it lacks the necessary restraint mechanism [10]. The government can adjust the land planning according to its own economic motivation. The fundamental solution to this problem is to separate planning adjustment right from ownership change right, and to stipulate more rigorous planning and editing procedures.

\subsection{Speed up the Establishment of Land Property Rights System}

We should speed up the formulation of land property rights system and further clarify the land property rights. In China, the phenomenon that some local governments earn money at the cost of land reserve decrease is caused by the lack of clear definition of land property right se final analysis [11]. The loopholes in the existing land property rights provide the opportunity for the illegal elements, which caused many people to occupy the land without fear, not only damaging the rights and interests of the landless peasants, but also buried the hidden dangers for the land management in China.

\subsection{Change the System of Government Monopoly of Land Market}

In accordance with the principle of "economic regulation, market supervision, social management and public service", land management and land administration should be completely separated [12]. The government should perform the 
duties of land administration and market supervision, while the land market activities are undertaken by the market subject. For some land which must be expropriated by the government because of public interest, the content of the public interest should be strictly defined and the market value of the land should be compensated [13].

\section{Summary}

Land resource management involves land planning, land policy formulation and implementation, land expropriation and so on. We should learn from the experience of American public land management to recognize the differences and promote the progress of land management in China. From the legal level, in China the land management law should be improved to reduce the use of land for unreasonable interests. From the management level, the Chinese government should separate management and administration and improve the rationality of decision-making; from the planning level, land management should be regulated and improve the scientific planning.

\section{References}

[1] Anderson, G.L. (1968) History of Public Land Law Development. Journal of American History, 56, 360.

[2] Callendar, M.H. (2002) Future Public Land Mobile Telecommunication Systems (FPLMTS). Third International Conference on Universal Personal Communications, San Diego, CA, 27 September-1 October 1994, 568-572.

[3] Sulak, A. and Huntsinger, L. (2007) Public Land Grazing in California: Untapped Conservation Potential for Private Lands? Rangelands, 29, 9-12. https://doi.org/10.2111/1551-501X(2007)29[9:PLGICU]2.0.CO;2

[4] Moote, M.A., Mcclaran, M.P. and Chickering, D.K. (1997) RESEARCH: Theory in Practice: Applying Participatory Democracy Theory to Public Land Planning. Environmental Management, 21, 877-889. https://doi.org/10.1007/s002679900074

[5] Callendar, M.H. (1994) Future Public Land Mobile Telecommunication Systems. IEEE Personal Communications, 1, 18. https://doi.org/10.1109/MPC.1994.337513

[6] Hibbard, B.H. (1924) A History of the Public Land Policies by B. H. Hibbard. A History of the Public Land Policies. The Macmillan Company, New York, 20-25.

[7] Tanaka, J.A., Torell, L.A. and Rimbey, N.R. (2005) Who Are Public Land Ranchers and Why Are They Out There? Western Economics Forum. Western Agricultural Economics Association.

[8] Roselaar, S.T. (2009) Public Land in the Roman Republic: A Social and Economic History of the Ager Publicus. Mnemosyne, 62, 705. https://doi.org/10.1163/156852510X456246

[9] Kovacs, K., Polasky, S., Nelson, E., et al. (2013) Evaluating the Return in Ecosystem Services from Investment in Public Land Acquisitions. PLoS ONE, 8, e62202. https://doi.org/10.1371/journal.pone.0062202

[10] Bestelmeyer, B.T., Herrick, J.E., Brown, J.R., et al. (2004) Land Management in the American Southwest: A State-and-Transition Approach to Ecosystem Complexity. Environmental Management, 34, 38-51. https://doi.org/10.1007/s00267-004-0047-4

[11] Polasky, S., Nelson, E., Camm, J., et al. (2008) Where to Put Things? Spatial Land 
Management to Sustain Biodiversity and Economic Returns. Biological Conservation, 141, 1505-1524. https://doi.org/10.1016/j.biocon.2008.03.022

[12] Smyth, A.J. and Dumasky, J. (1993) FELSM: An International Framework for Evaluating Sustainable Land Management. FAO, Chicago.

[13] Wang, G.Q., Zhang, J.Y., Jin, J.L., et al. (2012) Assessing Water Resources in China Using PRECIS Projections and VIC Model. Hydrology \& Earth System Sciences Discussions, 16, 231-240. 